\title{
Financial Inclusion, Bank Concentration and Firm Performance
}

\author{
Lisa Chauvet ${ }^{1}$, Luc Jacolin ${ }^{2}$
}

\author{
Working Paper \#615
}

\section{December 2016}

\begin{abstract}
This study focuses on the impact of financial inclusion and bank concentration on the performance of firms in developing and emerging countries. Using firm-level data for a sample of 55,596 firms in 79 countries, we find that financial inclusion, i.e. the distribution of financial services across firms, has a positive impact on firm growth. This positive impact is magnified when bank markets are less concentrated, a proxy for more competition among banks. We also find that more competitive banks favor firm growth only at high levels of financial inclusion, while bank concentration is particularly favorable to foreign and state-owned firms, and increases firm growth for low levels of financial inclusion. In countries with limited financial deepening, the quality of the banking system (financial inclusion and bank competition) may be as important to promote firm performance as its overall size.
\end{abstract}

Keywords: Financial inclusion, Bank concentration, Firm performance.

JEL classification : G10, O16, 050.

\footnotetext{
${ }^{1}$ IRD, LEDa, DIAL UMR 225, Banque de France, PSL, Université Paris-Dauphine, FERDI.

${ }^{2}$ Banque de France

Working Papers reflect the opinions of the authors and do not necessarily express the views of the Banque de France. This document is available on the Banque de France Website. 
L'accès au crédit a été identifié comme l'un des principaux obstacles au développement du secteur privé dans les pays en développement. Depuis les années 1990, une série d'études théoriques et empiriques ont montré l'existence d'une relation positive entre le développement financier, la performance des entreprises et la croissance économique. Toutefois, la littérature a surtout porté sur les effets du volume de crédit disponible pour le secteur privé (financial deepening ou " approfondissement financier) sur la croissance économique, plutôt que sur l'inclusion financière. Notre étude est essentiellement empirique et vise à clarifier l'impact de l'inclusion financière et du niveau de concentration bancaire sur la croissance des entreprises dans les pays en développement. Pour ce faire, nous tenterons de répondre aux questions suivantes: Dans quelle mesure l'inclusion financière des entreprises favorise-t-elle le développement du secteur privé ? La structure du marché bancaire, et en particulier la concentration des banques, influe-t-elle sur l'accès au crédit et sur la performance des firmes ? Une amélioration de l'inclusion financière permet-elle de compenser l'effet négatif d'une trop forte concentration bancaire dans les pays les plus pauvres?

Cette étude couvre trois courants de la littérature sur le développement financier et la performance économique. Le premier examine comment le volume de crédit disponible pour le secteur privé agit sur la croissance économique. Depuis la crise financière et économique de 2009 2008, l'accent a été mis sur l'existence d'une potentielle relation non-linéaire entre activité économique et approfondissement financier. C'est, en particulier le cas dans les pays développés, où le développement " excessif » des secteurs financiers peut aboutir à des rendements décroissants, un détournement des ressources vers d'autres secteurs productifs, ou un accroissement de la volatilité de l'activité économique.

Le deuxième courant analyse plus spécifiquement la façon dont l'inclusion financière influence les performances économiques. L'agenda international a récemment permis de mettre en lumière le rôle important joué par l'inclusion financière et la nécessité de mieux mesurer l'inclusion financière des ménages ou des entreprises (GPFI, 2013). Ainsi, les travaux menés sous l'égide du G20 suggèrent que l'impact du développement financier sur la croissance peut dépendre du degré d'inclusion financière des agents économiques.

Enfin, le dernier courant de la littérature examine l'effet de la structure du marché bancaire (concentration bancaire) sur la concurrence entre banques et, par ricochet, sur la diversité et la rentabilité des services bancaires. On y souligne le rôle des banques étrangères dans l'abaissement du coût des services bancaires et du crédit. En accélérant le développement financier, celles-ci élargissent la gamme des produits offerts et le portefeuille de clients, induisant des effets de diversification et une meilleure stabilité financière. Cependant, ces travaux montrent également que la déconcentration des systèmes bancaires ne se traduit pas forcément par des gains d'efficacité ou par une plus grande inclusion financière. Les banques étrangères peuvent adopter des stratégies d'écrémage pouvant fragiliser ou évincer des banques nationales, ce qui restreint le crédit aux entreprises plus risquées, et peut conduire à une baisse du volume de crédit. Les marchés bancaires moins concentrés peuvent également être moins stables et plus vulnérables aux crises que ceux qui sont plus concentrés et qui présentent une profitabilité bancaire plus élevée permettant d'amortir les crises et de réduire la prise de risque. 
Nous utilisons les enquêtes de la Banque mondiale sur les entreprises. Notre échantillon comprend 55596 entreprises représentatives au niveau national (et pour un double niveau de stratification, secteurs d'activité d'une part, et région d'autre part) réparties dans 79 pays en développement, couvrant l'Afrique, l'Amérique latine et l'Asie, sur la période 2006-2014. Le degré de concentration bancaire est mesuré au niveau pays en utilisant la base de données de la Banque mondiale Global Development Financial Database. L'inclusion financière dans chaque pays est mesurée au niveau secteur comme la part des entreprises ayant accès au crédit dans différents secteurs économiques.

Nos principaux résultats sont les suivants. II semble que l'inclusion financière ait un impact positif sur la croissance des entreprises et que la concurrence bancaire (une moindre concentration bancaire) amplifie cet effet. L'interaction positive entre l'inclusion financière et la concurrence bancaire suggère que ces deux variables peuvent être complémentaires. Nous montrons également que les effets de la concentration bancaire varient en fonction du développement économique et de l'inclusion financière, réconciliant ainsi les deux types de littérature exposées plus haut : la concentration bancaire peut favoriser la croissance des entreprises dans les pays en développement et émergents, mais de tels effets sont progressivement éliminés par le développement économique et l'inclusion financière.

Les tests classiques de robustesse (mesures alternatives, estimations sur différents échantillons géographiques et sectoriels) confirment les résultats de notre modèle de référence. Ainsi, si les bénéfices de l'inclusion financière sont partagés par l'ensemble des entreprises, indépendamment de leur taille ou de leur capacité à exporter, dans notre échantillon, les entreprises étrangères bénéficient le plus de l'inclusion financière et de la concentration des banques alors que les entreprises publiques bénéficient le plus de la concentration bancaire.

Au total, ces résultats suggèrent que l'approfondissement financier et la concurrence entre banques n'ont un impact significatif sur la croissance des entreprises que lorsque les portefeuilles de clients des banques et que l'accès au crédit bancaire deviennent plus inclusifs. 


\section{RÉSUMÉ : INCLUSION FINANCIÈRE, CONCENTRATION BANCAIRE ET PERFORMANCES DES}

\section{ENTREPRISES}

Cette étude essentiellement empirique vise à clarifier l'impact de l'inclusion financière et du niveau de concentration bancaire sur la croissance des entreprises dans les pays en développement. Sur la base d'un échantillon de 55596 entreprises réparties dans 79 pays en développement, couvrant l'Afrique, l'Amérique latine et l'Asie, sur la période 2006-2014, nous trouvons que I'inclusion financière, c'est-à-dire l'accès aux services financiers par les entreprises, a a un impact positif sur la croissance des firmes. Cet effet positif est d'autant plus important que le système bancaire est moins concentré, la concentration bancaire étant une proxy du niveau de concurrence entre banques.

Nous faisons également apparaitre qu'un secteur bancaire plus concurrentiel favorise la croissance des entreprises à des niveaux élevés d'inclusion financière, alors que le concentration bancaire est particulièrement favorable aux entreprises internationales et publiques. Dans les pays où le développement financier est faible, la qualité du secteur financier (concurrence, inclusion financière est aussi importante pour promouvoir la croissance des firmes que sa taille (approfondissement financier).

Mots-clés : Inclusion financière, Concentration bancaire, Performance des entreprises 


\section{Introduction}

Access to credit has been identified as one of the main obstacles to the development of private sector in developing countries. Since the early 1990s, a string of theoretical and empirical research studies have shown the existence of a positive relationship between financial development, firm performance, and economic growth. Financial development has been shown to improve the proportion of innovative and productivityenhancing investment projects, to reduce transaction costs, and more generally to improve the allocation of capital and risk management. The literature has so far mostly focused on financial deepening effects, i.e. the volume of credit available to the private sector.

This article builds on the existing literature to try and determine whether the "quality" of financial development affects firm performance. We examine two dimensions of the quality of financial development. The first is the financial inclusion of firms. The idea here is to distinguish between volume (financial depth) and the distribution of credit across firms (the share of firms in an industry with access to credit). The second dimension that we examine is the banking market structure, which may affect the volume as well as the price of credit. Examining aspects of financial development other than financial deepening - namely financial inclusion and bank concentration - may provide additional insight into the mechanisms through which financial development affects developing countries.

This paper relates to three strands of the literature on financial development and economic performance. The first examines how financial deepening affects economic growth. Since the 2009 financial and economic crisis, the literature has focused on the possibility of a non-linear relationship between economic activity and financial deepening, especially in developed countries, where large financial sectors may face diminishing returns (Philippon and Reshef, 2013), divert resources from other productive sectors (Deidda, 2006), or increase the volatility of economic activity (Easterly, Islam, and Stiglitz, 2001; Loayza and Ranciere, 2006). Empirical estimates show that, above thresholds ranging from $80 \%$ to $110 \%$ of private credit in GDP, the positive finance/growth link disappears and a case for "too much finance" may be made (Arcand, Berkes, and Panizza, 2015). Turning to developing countries, beyond caveats stemming from the large size of the informal sector (Guérineau and Jacolin, 2014), the question has been, conversely, to determine whether there is a case for "not enough finance" where undersized financial sectors, usually bank-led with little or no financial market development, play virtually no role in boosting economic growth, let alone corporate growth or productivity (Henderson, Papageorgiou, and Parmeter, 2013; Méon and Weill, 2010; Deidda and Fattouh, 2002). Rioja and Valev (2004) find that in countries with a share of private credit in GDP lower than $14 \%$, financial development has little effect on economic growth. Some specific weaknesses of developing 
countries, such as poor institutions (Demetriades and Hook Law, 2006), insufficient financial competition due to political deadlock (Rajan and Zingales, 2003), and high inflation (Rousseau and Wachtel, 2002), have been highlighted in the literature as dampening or suppressing the finance-growth relationship.

The second strand of the literature to which our paper relates deals more specifically with how financial inclusion affects economic outcomes. The international agenda has recently brought to light the significant role played by financial inclusion, that is, the extent to which households or firms have access to financial products and services. In addition to supply-side indicators of access to finance such as branch density, the number of ATMs or, more recently, market penetration of mobile phones as a proxy for mobile banking, a consensus has been reached to measure financial inclusion by the share of households or firms that have access to financial services (GPFI, 2013) and is now regularly surveyed by international organizations (IMF Financial Access Survey, Findex database). The literature suggests that the impact of financial deepening on growth may depend on the degree of financial inclusion. Abdmoulah and Jelili (2013) show for example that non-linearities between growth and financial development can be explained by access to finance, measured by the density of branches, which acts as a regime switching-trigger. Some studies find that the impact of financial inclusion on growth depends on firms' access to credit rather than households' (Beck et al., 2012), most notably by reducing the "financing gap" faced by small and medium sized firms and industries (GPFI, 2011). ${ }^{1}$ Financial inclusion reduces liquidity constraints and encourages investment. The distribution of credit across firms at the sectoral level therefore has important effects on the industrial structure, competition, or the degree of informality in the sector, particularly in low-income countries (Beck, Demirguc-Kunt, and Maksimovic, 2005). In some cases, the biggest or foreign-owned firms may reap most of the benefits of financial development, while smaller and locally-owned firms do not and in some cases are even crowded out from financing, as shown by Harrison and McMillan (2003) in Côte d'Ivoire.

Finally, the last strand of the literature to which this work can be related examines how the structure of the banking market (bank concentration) influences competitive behavior and hence the diversity and profitability of banking services (Beck et al., 2012; Northcott, 2004). This literature emphasizes in particular the role played by foreign banks in lowering the cost of banking services and credit (Demirguc-Kunt, Levine, and Min, 1998; De la Torre, Pería, and Schmukler, 2010). By accelerating financial development, they also provide a wider product and client base, which induces diversification effects and increases financial stability. Market structure effects may be particularly large in developing and emerging countries where lower efficiency and the high cost of credit magnifies the gains expected from the diffusion of international

\footnotetext{
${ }^{1}$ Households' access to credit may also increase economic growth, particularly if it finances durable goods rather than consumption (GPFI, 2013).
} 
best practices (Hermes and Lensink, 2003). Entering markets dominated for instance by large public banks may also yield important efficiency gains by lowering prevailing interest margins (Demirguc-Kunt, Laeven, and Levine, 2004). However, the literature also highlights that bank deconcentration may not necessarily yield the expected efficiency gains or favor financial inclusion. For instance, entering foreign banks may adopt cream-skimming strategies, i.e. targeting large and low-risk exporting companies and sovereign debt. Such strategies may force domestic banks out of the market, thereby constraining credit to riskier and more opaque firms, and leading to a decline of aggregate credit, as shown for example by Detragiache, Tressel, and Gupta (2008). Furthermore, Beck, De Jonghe, and Schepens (2013) show that less concentrated banking markets may also be less stable and more vulnerable to crises than concentrated ones, where higher profits provide buffers during crises and reduce incentives for excessive risk-taking. The authors also point out that a lower number of banks may facilitate bank supervision especially in countries with low administrative capacity. As shown by Claessens and Horen (2014), the effect of foreign bank entry thus yields different outcomes depending on the characteristics of the host country, in particular the quality of its regulatory framework, the importance of information asymmetries and the nationality of ownership (international banks from the OECD as opposed to pan-African groups for instance). These authors find that foreign bank entry may have a negative impact on credit in low-income countries, where they have a limited market share and where large information asymmetries limit the ability of banks to lend.

Our paper aims to disentangle the impact of financial deepening, financial inclusion, and the price and efficiency effects induced by changes in market structure in the banking sector. We use stacked World Bank Enterprise Surveys (WBES) for a set of 79 developing countries over the period 2006-2014. Our dependent variable is firm sales growth. We measure financial depth at the country level using the share of private credit in GDP. Bank concentration is also measured at the country level using the market share of the three largest banks in terms of balance sheet size. Both variables are available from the World Bank Global Financial Development Database. Financial inclusion is measured for each country, at the industry level, as the share of firms with access to credit. In our baseline estimates, access to credit is measured as having a loan from a financial institution, but we test the robustness of the results to alternative measures such as having an overdraft facility or financing part of the working capital with bank credit. Along with the three financial development variables - depth, inclusion, and bank concentration - we also include the interaction term of financial inclusion and bank concentration in order to understand to what extent the impact on growth of the entry of new banks into the market depends on wider access to credit among firms, i.e. whether these two dimensions are complementary or not. 
We show that, in developing and emerging countries, where financial deepening may be too limited to have a significant macroeconomic impact on growth, access to credit by a larger proportion of firms at the sectoral level enhances firm growth, except when the banking sector is very concentrated. We also find that bank concentration may help firm performance, but this effect turns negative as the level of economic development and financial inclusion rise. This suggests that policies that increase the access of firms to financial products and services may be as instrumental in boosting the firm performance and economic development as the promotion of financial markets or financial deepening alone.

The paper is structured as follows. Section 2 presents the model, while the data are presented in Section 3. Then in Section 4 we present the baseline results along with some robustness checks. In Section 5 we discuss the heterogeneity of the impact given specific firm characteristics in order to explore the potential crowding-out effects. Finally in Section 6 we conclude.

\section{Model}

In this article, we explore the role of financial inclusion in firm performance, assuming that financial inclusion affects firm performance differently according to the degree of bank competition, approximated by bank concentration. We thus estimate an econometric model of the following form:

$$
\begin{array}{r}
\operatorname{GROWTH}_{i, k, j,(t, t-3)}=\alpha+\beta X_{i, k, j, t}+\gamma Y_{j,(t, t-3)}+\delta \operatorname{CONCENTRATION}_{j,(t, t-3)} \\
+\lambda \operatorname{INCLUSION}_{k, j, t}+\theta \operatorname{CONCENTRATION} \operatorname{RI}_{j,(t, t-3)} \cdot \operatorname{INCLUSION}_{k, j, t}+\mu_{j}+\tau_{k, t}+\varepsilon_{i, k, j, t}
\end{array}
$$

where $G R O W T H_{i, k, j, t, t-3)}$ is sales growth of firm $i$, in industry $k$, country $j$. The growth rates are computed over three years, between $t$ and $t-3 . \mathrm{X}_{i, k, j, t}$ is a set of time-varying firm-level characteristics, including the initial value of sales. $\mathrm{Y}_{j,(t, t-3)}$ is a set of country-level variables averaged over the three years for which firm growth is computed. $\mathrm{Y}_{j,(t, t-3)}$ includes country size, income per capita (lagged i.e. averaged over the period spanning from t-3 to t-6), as well as an indicator of control of corruption. ${ }^{2} \mathrm{Y}_{j,(t, t-3)}$ also includes the degree of financial development as proxied by the share of private credit in GDP. Equation 1 accounts for country fixed effects, $\mu_{j}$, as well as industry x year dummies, $\tau_{k, t}$, which are included to account

\footnotetext{
${ }^{2}$ It ranges from weak (-2.5) to strong (2.5) control of corruption (Worldwide Governance Indicators).
} 
for time-varying heterogeneity within industries. Following Moulton (1990), the standard errors are clustered at the country level. ${ }^{3}$

Our model includes the interaction term of bank concentration (measured at the country level) with the industry-level measure of financial inclusion, CONCENTRATION ${ }_{j,(t, t-3)} \mathrm{xINCLUSION}_{k, j, t}$. This interaction term is intended to capture whether and to what extent banking market structure affects the impact of financial inclusion on firm performance.

\section{Data}

In order to estimate equation 1, we combine country-level financial characteristics with firm-level characteristics for a set of 79 developing countries. We use the stacked World Bank Enterprise Surveys (WBES) which cover the 2006-2014 period (repeated cross-section). Our sample is composed of more than 55,000 firms. The sample of countries, years and firms is presented in Appendix A.1. The baseline estimations only include developing and emerging countries. We exclude the high-income countries from the baseline sample. ${ }^{4}$ Conflict and post-conflict countries are also excluded from the main sample. Including both the high-income and conflict and post-conflict countries does not alter the results (see below). ${ }^{5}$

\subsection{Firm-level variables}

Firm-level data in local currencies have been deflated using the same base year $(100=2005)$ and converted into US dollars. GDP deflators and exchange rates are obtained from the IMF's International Financial Statistics (IFS). Each survey of the WBES includes information on the sales in the year preceding the survey, as well as three years before. This allows us to compute the annual average growth rate of sales over three years for each available survey, $\mathrm{GROWTH}_{i, k, j,(t, t-3)}$. As it is commonly done in the literature, we drop the one percent of firms with extreme growth rates. Our specification draws on Beck, Demirguc-Kunt, and Maksimovic (2005) and Harrison, Lin, and Xu (2014). We include the size of the firm, $\mathrm{SIZE}_{i, k, j, t}$, which can take three values: one when the firm is small (less than 20 employees), two when it employs between 20 and 100 employees, and three when it is large (more than 100 employees). We also control for the kind of

\footnotetext{
${ }^{3}$ The results in Tables 2-5 are virtually the same when the standard errors are clustered at the sector level or at the country and year levels.

${ }^{4}$ We exclude the following high-income countries: The Bahamas, Barbados, Bulgaria, Croatia, Czech Republic, Estonia, Germany, Greece, Hungary, Ireland, Israel, Republic of Korea, Latvia, Lithuania, Oman, Poland, Portugal, Romania, Russian Federation, Serbia and Montenegro, Slovakia, Slovenia, Spain, St. Kitts and Nevis, Sweden, and Trinidad and Tobago.

${ }^{5}$ Conflict and post-conflict countries are Burundi, Afghanistan, Angola, Algeria, Chad, Congo, Dem. Rep., Côte d'Ivoire, Eritrea, Iraq, Israel, Liberia, Nepal, Nigeria, Sierra Leone, South Sudan, Sudan, Sri Lanka, West Bank and Gaza, Yemen, Myanmar, and Ukraine.
} 
ownership by including a dummy variable which is equal to one when part (or all) of the firm is owned by a foreign entity, FOREIGN ${ }_{i, k, j, t}$, as well as a dummy variable which is equal to one when part (or all) of the firm is owned by the State, $\mathrm{STATE}_{i, k, j, t}$. Our specification also includes a dummy variable, $\mathrm{EXPORT}_{i, k, j, t}$, which is equal to one when the firm exports part of its production either directly or indirectly (as a supplier of an exporting firm). Finally, we include the logarithm of lagged sales (deflated and converted into US dollars) to account for catching-up effects.

In all specifications we also control for firms' access to credit. Our main measure is a dummy variable which is equal to one if the firm currently has a loan from a financial institution, $\operatorname{LOAN}_{i, k, j, t}$. As an alternative measure, we also use a dummy variable which is equal to one if the firm has an overdraft facility, $\operatorname{OVERDRAFT}_{i, k, j, t}$. Finally, the last alternative measure of firms' access to finance is a dummy variable which is equal to one if the firm finances part of its working capital with bank credit, WC-BANK $\mathrm{W}_{i, k, j, t}$.

Table 1 presents the basic descriptive statistics of these firm-level data. Our sample of firms is mostly composed of large formal firms. One quarter is outward-looking, exporting either directly or indirectly. Ten and one percent are foreign or state-owned respectively. Among our sample of firms, $40 \%$ currently have a loan, $47 \%$ have an overdraft facility, and $37 \%$ finance part of their working capital using a bank credit. This confirms that access to overdraft facilities represents the first main step towards financial inclusion for firms in developing and emerging countries.

\subsection{Country-industry-level variables}

We measure financial inclusion at the country-industry level. Using standard international measures of financial inclusion, we construct financial inclusion, INCLUSION-LOAN $k, j, t$, as the share of firms in industry $k$ of country $j$ which have a bank loan. Our intention is to capture the more or less even distribution of credit among firms at the country-sector level. Unlike a firm's individual access to credit, which depends on its own risk characteristics (and the bank's choice to grant access to credit to an individual client), country-sectoral financial inclusion is mainly a function both of the characteristics of sectoral financing needs, which are likely to be similar across countries (Rajan and Zingales, 1998), and each country's financial development. The WBES data cover 23 sectors and the distribution of firms across sectors is presented in Table A.2 in the Appendix.

Table 1 presents some descriptive statistics of INCLUSION-LOAN ${ }_{k, j, t}$. On average, the share of firms with a loan in a specific sector is $40 \%$, but the variance is quite large, with some country-sectors having no loans at all, while in others all firms have a loan. We also test the robustness of the results using 
INCLUSION-OVERDRAFT $_{k, j, t}$, which reflects the share of firms in the industry that have an overdraft facility, which is slightly higher than the share of firms with a loan. We also test the robustness of our results using a third definition of inclusion, namely the share of firms in the industry-country that finance part or all of their working capital with bank credit, INCLUSION-WC-BANK $k, j, t$.

\subsection{Country-level variables}

The estimations control for a large array of country-level time-varying factors. We include the logarithm of income per capita lagged one period to avoid endogeneity problems as much as possible, $\operatorname{INCOME}_{j,(t-3, t-6)}$. We also control for the size of the market using the logarithm of the population, POPULATION $_{j,(t, t-3)}$. Finally, we include a proxy for the quality of economic institutions using an indicator of the control of corruption, CORRUPTION $\operatorname{Con}_{j,(t,-3)}$. This indicator is computed by Kaufmann, Kraay, and Mastruzzi (2011) and ranges from weak (-2.5) to strong $(+2.5)$ control of corruption. We also include a measure of financial development, $\operatorname{FINDEV}_{j,(t, t-3)}$, which is defined as the share of private credit from financial banks and other financial institutions in GDP, and averaged over three years.

Our main variable of interest is bank concentration, which is measured at the country level using three different variables: the market share of the three largest banks in terms of balance sheet size CONCENTRATION $_{j,(t, t-3)}-$, the market share of the the five largest banks - CONCENTRATION- $5_{j,(t, t-3)}$ - , and a Lerner index - CONCENTRATION-Lerner ${ }_{j,(t, t-3)}$. This latter variable is defined as the difference between output prices and marginal costs (relative to prices). Prices are calculated as total bank revenue over assets, whereas marginal costs are obtained from an estimated translog cost function with respect to output. Higher values of the Lerner index indicate less bank competition. It is calculated from underlying bank-by-bank data from Bankscope. Financial development and bank concentration variables are all obtained from the World Bank Global Financial Development Data (GFDD) web page.

Table 1 presents some descriptive statistics of the country-level variables used in our model. On average, financial development represents $32 \%$ of GDP. This average hides a large heterogeneity across countries. For example, $10 \%$ of the firms in the baseline sample are located in countries with financial development lower than $12 \%$ of GDP, while another $10 \%$ of the firms are located in countries with financial development higher than $70 \%$ of GDP. Bank concentration is rather high in our sample, with the three largest banks representing on average $74 \%$ of the bank market. Overall, the developing and emerging countries in our sample display lower financial development and higher bank concentration than developed countries. 
Table 1: Summary statistics.

\begin{tabular}{|c|c|c|c|c|c|c|}
\hline Variables & & $\mathbf{N}$ & mean & sd & $\min$ & $\max$ \\
\hline \multicolumn{7}{|c|}{ Firm-level variables } \\
\hline GROWTH $_{i, k, j,(t, t-3)}$ & & 55,596 & 0.05 & 0.35 & -1.00 & 4.71 \\
\hline $\operatorname{SALES}_{i, k, j, t-3}$ & logarithm & 55,596 & 13.08 & 2.48 & 2.62 & 28.62 \\
\hline $\mathrm{STATE}_{i, k, j, t}$ & dummy & 55,596 & 0.01 & 0.12 & 0.00 & 1.00 \\
\hline FOREIGN $_{i, k, j, t}$ & dummy & 55,596 & 0.10 & 0.30 & 0.00 & 1.00 \\
\hline $\operatorname{EXPORT}_{i, k, j, t}$ & dummy & 55,596 & 0.24 & 0.43 & 0.00 & 1.00 \\
\hline $\mathrm{SIZE}_{i, k, j, t}$ & & 55,596 & 1.76 & 0.80 & 0.00 & 3.00 \\
\hline $\operatorname{LOAN}_{i, k, j, t}$ & dummy & 55,596 & 0.40 & 0.49 & 0.00 & 1.00 \\
\hline OVERDRAFT $_{i, k, j, t}$ & dummy & 55,120 & 0.47 & 0.50 & 0.00 & 1.00 \\
\hline $\mathrm{WC} \mathrm{BANK}_{i, k, j, t}$ & dummy & 53,480 & 0.37 & 0.48 & 0.00 & 1.00 \\
\hline \multicolumn{7}{|c|}{ Country-industry-level variable } \\
\hline INCLUSION-LOAN $_{k, j, t}$ & & 2,221 & 0.40 & 0.30 & 0.00 & 1.00 \\
\hline INCLUSION-OVERDRAFT $_{k, j, t}$ & & 2,203 & 0.45 & 0.33 & 0.00 & 1.00 \\
\hline INCLUSION-WC-BANK $_{k, j, t}$ & & 1,943 & 0.33 & 0.28 & 0.00 & 1.00 \\
\hline \multicolumn{7}{|c|}{ Country-level variable } \\
\hline FINDEV $_{j, t}$ & \% GDP & 120 & 0.32 & 0.23 & 0.00 & 1.30 \\
\hline $\operatorname{INCOME}_{j,(t-3, t-6)}$ & logarithm & 120 & 7.36 & 1.04 & 5.17 & 9.42 \\
\hline POPULATION $_{j,(t, t-3)}$ & logarithm & 120 & 16.05 & 1.67 & 11.35 & 21.01 \\
\hline CORRUPTION $_{j,(t, t-3)}$ & & 120 & -0.39 & 0.58 & -1.42 & 1.37 \\
\hline CONCENTRATION $_{j,(t, t-3)}$ & & 120 & 0.74 & 0.20 & 0.25 & 1.00 \\
\hline CONCENTRATION- $5_{j,(t, t-3)}$ & & 102 & 0.82 & 0.16 & 0.33 & 1.00 \\
\hline CONCENTRATION-Lerner $_{j,(t, t-3)}$ & & 97 & 0.27 & 0.11 & -0.02 & 0.60 \\
\hline
\end{tabular}

Note on the number of observations $(\mathrm{N})$ :

- 55,596 is the total number of firms in the baseline sample

- 2,221 is the total number of country-sector-years in the baseline sample

- 120 is the total number of country-years (79 countries with one to three years for each), see Appendix A.1

\section{The impact of financial inclusion and bank concentration on firm growth}

\subsection{Baseline results}

The estimation of equation 1 is reported in Table 2. Column (1) of Table 2 is estimated using the OLS estimator, with country and sector-year dummies and standard errors clustered at the country level. The firm-level control variables suggest that there is a catch-up effect - firms with low levels of sales in $t-3$ have 
better growth prospects in $t$. State-owned firms display lower growth rates, while foreign-owned companies and larger and exporting firms perform better. Turning to the country-level control variables, column (1) suggests that firm performance is negatively associated with the level of development, in line with the idea of a catching-up effect. Country size and the control of corruption are not significantly correlated with firm growth for our sample of countries.

Regarding our variables of interest, column (1) in Table 2 suggests that firm growth is positively correlated with firms' access to credit, $\mathrm{LOAN}_{i, k, j, t}$. It is also positively correlated with financial inclusion measured at the sector level, INCLUSION-LOAN $k, j, t$. The impact of financial inclusion on firm growth is however dampened by bank concentration, which can be interpreted as a bank market structure effect: less concentrated bank markets are associated with wider access to financial services by a larger spectrum of enterprises. Bank competition also has various efficiency effects such as driving the price of credit down and improving financial infrastructure. We interpret the negative effect of the interaction term of financial inclusion with bank concentration as showing the positive effects of bank competition on both firms' access to credit and the price of credit. As indicated in the second row from the bottom of Table 2, our estimates suggest that when bank concentration is higher than $72 \%$ financial inclusion at the sector level has a negative effect on firm performance. In our sample, 19,288 firms (34\%) are located in countries that display bank concentration above this threshold.

However bank concentration itself, measured at the country level, $\operatorname{CONCENTRATION}_{j,(t, t-3)}$, has a positive effect on firm growth. The positive effect of bank concentration may appear counter-intuitive at first sight, but it may be explained by suboptimal banking market conditions in developing and emerging countries. First, one interpretation may be that in infant bank markets there may only be market space for a limited number of financial institutions and new entrants may impair the solvency and stability of the banking sector, which in turn may constrain the supply of credit. Second, as shown by Detragiache, Tressel, and Gupta (2008), entering banks may in some countries adopt cream skimming strategies by focusing on large private and public borrowers instead of developing a wider client base, hence driving profits and credit down. Competition effects may depend on the nationality of entering banks (local, regional, or OECD-based), which determines their knowledge of local markets and risk-taking. Finally, new bank entry may impede credit in countries with poor regulatory frameworks and where information asymmetries are large. Combined with the negative coefficient of the interaction term between financial inclusion and bank concentration, the last row of Table 2 shows that bank concentration has a positive effect on firm growth for levels of financial inclusion lower than $85 \%$ of firms with a bank loan. This suggests that only for sufficiently inclusive financial systems 
does bank concentration have a negative effect on firm performance or, conversely, that bank competition improves firm performance when it also results in a widening of banks' client base, i.e. when it is associated with more financial inclusion.

Finally, financial deepening, measured at the country level by the share of private credit in the economy, FINDEV $_{j,(t, t-3)}$, is not found to significantly affect firm performance, which, combined with our previous results, suggests that what matters most is not the aggregate level of credit from the banking sector but how it is distributed among firms. This also suggests that the price effect of bank competition may be larger than its quantity effect: in developing countries, an increase in the volume of private credit is not necessarily associated with more firms having access to credit, which may explain why $\operatorname{FINEV}_{j,(t, t-3)}$ has no significant correlation with firm growth in our analysis.

In columns (2) and (3) of Table 2 we test the robustness of the baseline estimate with respect to the potential endogeneity of the firm-level controls. We do this in two ways. First, we re-aggregate the firm-level controls at the country-sector-year level, as is usually performed in the literature (Harrison, Lin, and Xu, 2014). We thus replace the firm-level variables with the average value of initial sales and size of firms belonging to the same industry, and with the share of firms in the industry which are foreign-owned, state-owned, and exporting. We do not re-aggregate $\operatorname{LOAN}_{i, k, j, t}$ (whether the firms have a loan from a financial institution) at the industry level because it is already captured in INCLUSION-LOAN $k, j, t$. Except for SIZE $\mathrm{S}_{k, j, t}$ and SALES $_{k, j, t}$ all the firm-level characteristics, once re-aggregated at the industry level, lose their significance. More important, our variables of interests, namely INCLUSION-LOAN $k, j, t$, CONCENTRATION $_{j, t, t-3)}$, and their interaction term, are not altered by this change, either in terms of significance or in magnitude.

Second, we address the potential endogeneity of firm-level variables that may stem from time unvarying confounding factors. To do this, we account for a firm fixed effect. We stacked firm-level panel data from the World Bank Enterprise Surveys (WBES). Our sample is then composed of 3,745 firms in 25 developing and emerging countries, with two points in time for each firm. The countries for which we have the information as to whether the firm was interviewed twice are marked with a star in Appendix A.1. Column (3) of Table 2 suggests that accounting for firm-level time-unvarying unobservable heterogeneity does not alter the conclusions of our baseline estimate (even at the cost of restricting the sample of firms and countries). 
Table 2: Baseline estimates of the impact of financial inclusion and bank concentration on firm growth.

\begin{tabular}{|c|c|c|c|}
\hline & $\begin{array}{c}\text { Baseline } \\
\text { (1) }\end{array}$ & $\begin{array}{l}\text { Aggregation of } \\
\text { firm-level controls } \\
(2)\end{array}$ & $\begin{array}{l}\text { Firm fixed effect } \\
\qquad(3)\end{array}$ \\
\hline $\operatorname{INCLUSION-LOAN}_{k, j, t}$ & $\begin{array}{c}0.366^{* * *} \\
(2.86)\end{array}$ & $\begin{array}{c}0.390^{* * *} \\
(3.07)\end{array}$ & $\begin{array}{c}0.942^{* *} \\
(2.70)\end{array}$ \\
\hline INCLUSION-LOAN $_{k, j, t}$ x CONCENTRATION CON, $_{j, t-3)}$ & $\begin{array}{c}-0.511^{* * *} \\
(-3.03)\end{array}$ & $\begin{array}{c}-0.498^{* * *} \\
(-2.85)\end{array}$ & $\begin{array}{c}-1.066^{* *} \\
(-2.11)\end{array}$ \\
\hline CONCENTRATION $_{j,(t, t-3)}$ & $\begin{array}{c}0.433^{* * *} \\
(3.86)\end{array}$ & $\begin{array}{c}0.404^{* * *} \\
(3.85)\end{array}$ & $\begin{array}{c}0.993^{* * *} \\
(2.85)\end{array}$ \\
\hline $\operatorname{FINDEV}_{j,(t, t-3)}$ & $\begin{array}{l}-0.339 \\
(-1.45)\end{array}$ & $\begin{array}{l}-0.373 \\
(-1.59)\end{array}$ & $\begin{array}{c}-0.628^{* *} \\
(-2.19)\end{array}$ \\
\hline $\operatorname{LOAN}_{i, k, j, t}$ & $\begin{array}{l}0.0344^{* * *} \\
(3.14)\end{array}$ & $\begin{array}{c}-0.00350 \\
(-0.27)\end{array}$ & $\begin{array}{c}0.0555^{* * *} \\
(4.30)\end{array}$ \\
\hline $\operatorname{LNSALES}_{i, k, j, t-3}$ & $\begin{array}{c}-0.0826^{* * *} \\
(-4.97)\end{array}$ & $\begin{array}{c}-0.0783^{* * *} \\
(-5.91)\end{array}$ & $\begin{array}{c}-0.123^{* * *} \\
(-5.72)\end{array}$ \\
\hline STATE $_{i, k, j, t}$ & $\begin{array}{c}-0.0357^{* * *} \\
(-3.24)\end{array}$ & $\begin{array}{l}0.136 \\
(1.30)\end{array}$ & $\begin{array}{l}0.103 \\
(1.03)\end{array}$ \\
\hline FOREIGN $_{i, k, j, t}$ & $\begin{array}{c}0.0354^{* * *} \\
(3.01)\end{array}$ & $\begin{array}{c}0.0814 \\
(1.64)\end{array}$ & $\begin{array}{l}0.0111 \\
(0.47)\end{array}$ \\
\hline $\operatorname{EXPORTS}_{i, k, j, t}$ & $\begin{array}{c}0.0664^{* *} \\
(2.01)\end{array}$ & $\begin{array}{c}0.0292 \\
(0.62)\end{array}$ & $\begin{array}{l}0.0525^{* * *} \\
(2.99)\end{array}$ \\
\hline $\mathrm{SIZE}_{i, k, j, t}$ & $\begin{array}{c}0.110^{* * *} \\
(4.21)\end{array}$ & $\begin{array}{c}0.0793^{* *} \\
(2.29)\end{array}$ & $\begin{array}{c}0.0628^{* *} \\
(3.30)\end{array}$ \\
\hline $\operatorname{LNINCOME}_{j,(t-3, t-6)}$ & $\begin{array}{c}-0.802^{* * *} \\
(-2.84)\end{array}$ & $\begin{array}{c}-0.775^{* * *} \\
(-2.86)\end{array}$ & $\begin{array}{c}0.227^{* * *} \\
(3.14)\end{array}$ \\
\hline $\operatorname{LNPOPULATION}_{j,(t, t-3)}$ & $\begin{array}{l}0.599 \\
(1.05)\end{array}$ & $\begin{array}{l}0.535 \\
(0.95)\end{array}$ & $\begin{array}{l}-0.677 \\
(-0.78)\end{array}$ \\
\hline CORRUPTION $_{j,(t, t-3)}$ & $\begin{array}{l}0.101 \\
(0.64)\end{array}$ & $\begin{array}{l}0.101 \\
(0.67)\end{array}$ & $\begin{array}{l}0.0217 \\
(0.11)\end{array}$ \\
\hline Observations & 55,596 & 55,596 & 7,490 \\
\hline Countries & 79 & 79 & 25 \\
\hline Country dummies & yes & yes & no \\
\hline Firm fixed effect & no & no & yes \\
\hline Sector-year dummies & yes & yes & no \\
\hline Year dummies & no & no & yes \\
\hline Threshold in CONCENTRATION $_{j,(t, t-3)}^{(a)}$ & 0.716 & 0.783 & 0.884 \\
\hline Threshold in INCLUSION-LOAN IN,j,t $^{(b)}$ & 0.847 & 0.811 & 0.932 \\
\hline
\end{tabular}

Robust standard errors clustered at the country level. $t$-Student in parenthesis. ${ }^{* * *} \mathrm{p}<0.01,{ }^{* *} \mathrm{p}<0.05,{ }^{*} \mathrm{p}<0.1$.

(a) Level of CONCENTRATION CO $_{j, t-3)}$ above which INCLUSION-LOAN $k, j, t$ has a negative impact

(b) Level of INCLUSION-LOAN $k, j, t$ above which CONCENTRATION I $_{j,(t, t-3)}$ has a negative impact

\subsection{Robustness checks}

In what follows we provide further robustness checks of the baseline results presented in Table 2 along two dimensions: (1) the measures of inclusion and concentration; and (2) sample dependence.

Table 3 re-estimates our baseline estimation (regression (1) in Table 2) using alternative measures of 
financial inclusion (one based on overdrafts and the other based on the share of working capital financed with bank credit) and bank concentration (one based on the concentration of the five main banks and the other based on a Lerner index). Panel A of Table 3 uses the same measure of bank concentration as in the baseline specification (market share of the three main banks). The first column, where inclusion is defined by having a bank loan, merely reproduces our baseline result. When in columns (2) and (3) we switch to the two alternative measures of inclusion the results are unaltered. Then in Panel B we switch to measuring bank concentration using the market share of the five main banks (instead of the three main banks), but again the results are unaltered whatever the measure of financial inclusion used.

Finally in Panel C, we use a measure of bank concentration based on a Lerner index. This drastically reduces the sample of firms, which drops to around 48,000. However, the results are very similar to those obtained in Panels A and B, but are less robust, as illustrated by the loss in significance of the coefficient of financial inclusion in column (1).

Table 4 presents the results when the baseline estimates is tested for sample dependence. In this Table we measure financial inclusion using the share of firms with a loan, INCLUSION-LOAN $k, j, t$, and bank concentration as the market share of the three main banks, CONCENTRATION $j,(t, t-3)$.

We first add to the sample the post-conflict countries (column (1)) and the high-income countries (column (2)). The results are very similar to the baseline estimate presented in Table 2. Then in columns (3) to (5) we sequentially drop the countries from Sub-Saharan Africa, Asia, and Latin America. Again the results are unaltered suggesting that they are not driven by one of the sub-regions in the sample. Finally, in the last column, we only keep manufacturing firms, but again the results are very similar, both in terms of significance and magnitude. The last two rows of Table 4 suggest that the threshold in $\operatorname{CONCENTRATION}_{j,(t, t-3)}$ for which financial inclusion has a negative effect on firm performance is higher on samples of countries which are less developed (adding conflict and post-conflict countries and dropping Latin America). When services are excluded, the degree of bank concentration must be very high for financial inclusion to affect firm performance negatively (above 98.9\%), which is case of only 2,909 firms in our sample of manufacturing firms. These results suggest that financial inclusion is favorable for firm growth even for high levels of bank concentration when the firm is located in the poorest countries, as well as for manufacturing firms. 
Table 3: Using an alternative measure of financial inclusion and bank concentration.

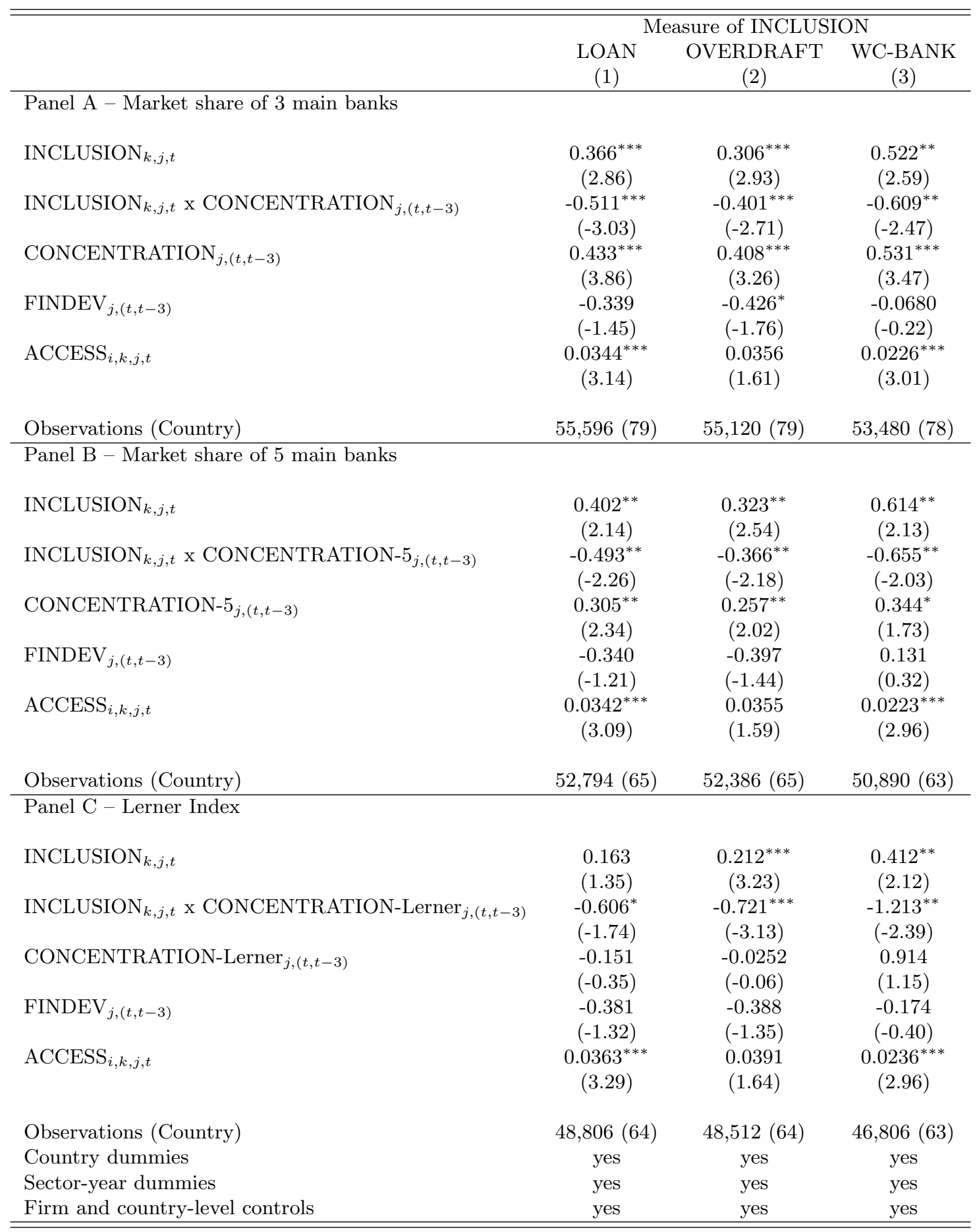

Robust standard errors clustered at the country level. $t$-Student in parenthesis. ${ }^{* * *} \mathrm{p}<0.01,{ }^{* *} \mathrm{p}<0.05,{ }^{*} \mathrm{p}<0.1$. 


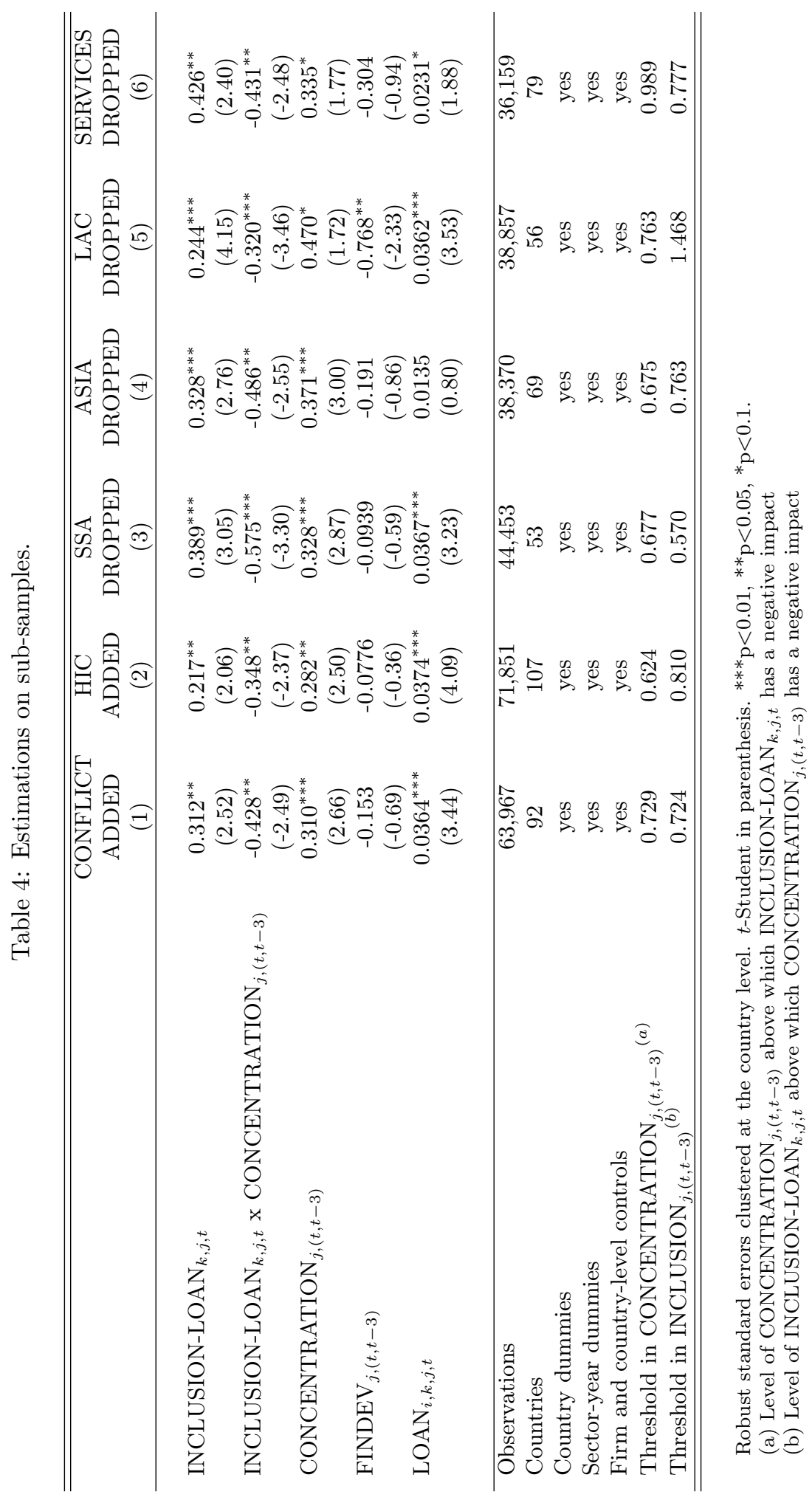




\section{Do some firms benefit more from financial inclusion than oth- ers?}

The last step in our analysis consists in examining whether the impact of financial inclusion and bank concentration depends on some specific country and firm characteristics. We have found so far that financial inclusion has a positive effect on firm growth, which is dampened by the degree of concentration of the banking sector. This non-linear relationship may stem from the fact that a more concentrated banking sector tends to charge higher credit prices and to concentrate its lending on a small number of large firms. We also find that bank concentration in developing and emerging countries affects firm performance positively, notably when financial inclusion is low. For higher levels of financial inclusion, a certain degree of bank competition is more favorable to firm growth.

We now examine whether firm characteristics - firm size, type of ownership, and exporting activity - affect the relationship we just highlighted. To do so, we estimate a model in which inclusion and concentration are both interacted with firm-level characteristics. In column (1) of Table 5 we find that the impact of both financial inclusion and bank concentration on firm performance does not depend on the size of the firm, SIZE $E_{i, k, j, t}$. Controlling for the firm's access to credit (with the $\operatorname{LOAN}_{i, k, j, t}$ variable) whether the firm is small or large does not alter the way it benefits from financial inclusion or bank concentration. A similar conclusion emerges when comparing the exporting and non-exporting firms in Column (2) of Table 5. Controlling for their access to credit, and whether they are outward-looking or not, the impact of financial inclusion and bank concentration does not depend on their exporting activity (neither of the interaction

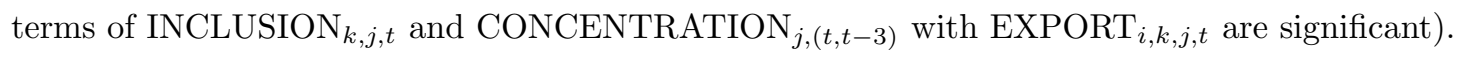

However, we find that the kind of ownership as shown in columns (3) and (4) of Table 5 may affect how financial inclusion and bank concentration boost firm growth. Indeed, both interaction terms

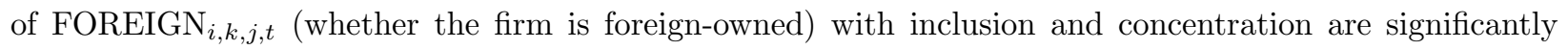
positive. Computing the turning points, we find that when FOREIGN $_{i, k, j, t}$ equals one, INCLUSION $_{k, j, t}$ has a positive effect on firm growth for levels of $\operatorname{CONCENTRATION~}_{j,(t, t-3)}$ below $0.85 \%$, while when FOREIGN $_{i, k, j, t}$ equals zero, this threshold is lower, at around $0.70 \%$. This suggests that foreign-owned firm benefit from financial inclusion up to higher levels of bank concentration compared to locally-owned firms. Column (3) of Table 5 also suggests that when FOREIGN ${ }_{i, k, j, t}$ equals one the level of financial inclusion for which bank concentration starts having a negative impact on firm performance is around $0.91 \%$, while it is around $81 \%$ when FOREIGN ${ }_{i, k, j, t}$ equals zero. This suggests that foreign-owned firms benefit from bank 
concentration up to higher levels of financial inclusion compared with other firms.

State-owned enterprises also seem to benefit more from bank concentration than other kinds of firms, as illustrated in column (4) of Table 5 . When $\operatorname{STATE}_{i, k, j, t}$ equals one, bank concentration always has a positive impact on firm growth (the turning point in $\operatorname{INCLUSION}_{k, j, t}$ is above one), while when $\mathrm{STATE}_{i, k, j, t}$ equals zero bank concentration has a positive effect on firm growth until financial inclusion reaches $0.85 \%$; only for higher levels of financial inclusion does the firm benefit from more bank competitiveness.

These results confirm that foreign-owned firms tend to benefit more than other firms from financial inclusion and bank concentration, whereas state-owned firms benefit only from bank concentration. These results provide additional support to our view that, in our sample of developing and emerging countries, bank concentration mostly favors foreign and state-owned firms and that bank competition only has a positive impact on overall firm growth if credit is widely supplied to firms, i.e. if financial inclusion is broad enough to include not only lower risk public and foreign firms but also locally-owned private firms.

The impact of financial inclusion and bank concentration may not only depend on firm-level characteristics but also on country-level characteristics. In columns (5) and (6) of Table 5 we thus examine whether the impact of financial inclusion and bank concentration depends on the level of financial and economic development of countries. We find that the level of financial development, $\operatorname{FINDEV}_{j,(t, t-3)}$, does not alter the relationships between inclusion, concentration and growth: neither of interaction variables of financial inclusion and bank concentration with financial development are significant.

When interacting our variables of interest with income per capita, we find that both interaction terms have a significantly negative effect on firm growth. It seems that for more developed countries the relationships presented in the baseline results of Table 2 are dampened. More specifically, assuming the level of bank concentration is the average of the sample $(0.74 \%)$, then financial inclusion has a positive impact on firm growth until the country reaches a level of income per capita higher than 2,500 USD. Then financial inclusion tends to impede firm growth. Column (6) also suggests that for a level of financial inclusion around the average $(0.4 \%)$ bank concentration has a positive impact on firm performance in countries with income per capita below 5,000 USD. We interpret this as yet another example of the non-linearity of the relationship between financial and economic development: in low and lower middle-income countries, banking systems are not large enough to impact firm growth and what matters is financial inclusion and how banks choose to compete with each other. As the level of economic development rises in emerging countries, the expected positive relationships between firm performance and bank competition take hold and financial inclusion may not be as relevant. 
Table 5: The effect of financial inclusion and development depending on firm and country characteristics.

\begin{tabular}{|c|c|c|c|c|c|c|}
\hline \multirow[t]{2}{*}{ VARIABLE: } & \multicolumn{4}{|c|}{ Firm-level characteristics } & \multicolumn{2}{|c|}{ Country-level characteristics } \\
\hline & $\begin{array}{l}\text { SIZE } \\
(1)\end{array}$ & $\begin{array}{l}\text { EXPORTS } \\
(2)\end{array}$ & $\begin{array}{c}\text { FOREIGN } \\
(3)\end{array}$ & $\begin{array}{l}\text { STATE } \\
(4)\end{array}$ & $\begin{array}{l}\text { FINDEV } \\
(5)\end{array}$ & $\begin{array}{l}\text { LNINCOME } \\
(6)\end{array}$ \\
\hline $\operatorname{INCLUSION}_{k, j, t}$ & $\begin{array}{c}0.314^{* * *} \\
(3.04)\end{array}$ & $\begin{array}{c}0.341^{* * *} \\
(2.91)\end{array}$ & $\begin{array}{c}0.368^{* * *} \\
(2.84)\end{array}$ & $\begin{array}{c}0.366^{* * *} \\
(2.86)\end{array}$ & $\begin{array}{c}0.358^{* * *} \\
(2.96)\end{array}$ & $\begin{array}{c}1.113^{* * *} \\
(5.44)\end{array}$ \\
\hline CONCENTRATION $_{j,(t, t-3)}$ & $\begin{array}{c}0.387^{* * *} \\
(3.16)\end{array}$ & $\begin{array}{c}0.422^{* * *} \\
(3.77)\end{array}$ & $\begin{array}{c}0.429^{* * *} \\
(3.82)\end{array}$ & $\begin{array}{c}0.432^{* * *} \\
(3.85)\end{array}$ & $\begin{array}{c}0.519^{* *} \\
(2.03)\end{array}$ & $\begin{array}{c}4.672^{* * *} \\
(3.44)\end{array}$ \\
\hline $\operatorname{INCLUSION}_{k, j, t} \times \mathrm{CONCENT}_{\cdot j,(t, t-3)}$ & $\begin{array}{c}-0.522^{* * *} \\
(-3.26)\end{array}$ & $\begin{array}{c}-0.545^{* * *} \\
(-3.13)\end{array}$ & $\begin{array}{c}-0.529^{* * *} \\
(-3.06)\end{array}$ & $\begin{array}{c}-0.512^{* * *} \\
(-3.05)\end{array}$ & $\begin{array}{c}-0.515^{* * *} \\
(-2.88)\end{array}$ & $\begin{array}{c}-0.483^{* * *} \\
(-3.12)\end{array}$ \\
\hline $\operatorname{INCLUSION}_{k, j, t} \mathrm{x}$ VARIABLE & $\begin{array}{c}0.0340 \\
(0.87)\end{array}$ & $\begin{array}{l}0.177 \\
(1.25)\end{array}$ & $\begin{array}{c}0.0834^{*} \\
(1.83)\end{array}$ & $\begin{array}{c}0.00469 \\
(0.07)\end{array}$ & $\begin{array}{c}0.0243 \\
(0.30)\end{array}$ & $\begin{array}{c}-0.0969^{* * *} \\
(-3.92)\end{array}$ \\
\hline $\mathrm{CONCENT}_{\cdot j,(t, t-3)} \mathrm{x}$ VARIABLE & $\begin{array}{c}0.0321 \\
(1.63)\end{array}$ & $\begin{array}{c}0.0455 \\
(1.32)\end{array}$ & $\begin{array}{c}0.0524^{* *} \\
(2.21)\end{array}$ & $\begin{array}{c}0.0896^{*} \\
(1.76)\end{array}$ & $\begin{array}{l}-0.322 \\
(-0.47)\end{array}$ & $\begin{array}{c}-0.525^{* * *} \\
(-3.27)\end{array}$ \\
\hline VARIABLE & $\begin{array}{c}0.084^{* * *} \\
(3.97)\end{array}$ & $\begin{array}{l}-0.019 \\
(-0.48)\end{array}$ & $\begin{array}{l}-0.026 \\
(-1.22)\end{array}$ & $\begin{array}{c}-0.070^{* * *} \\
(-3.16)\end{array}$ & $\begin{array}{l}-0.143 \\
(-0.35)\end{array}$ & $\begin{array}{l}-0.218 \\
(-0.74)\end{array}$ \\
\hline $\operatorname{LOAN}_{i, k, j, t}$ & $\begin{array}{c}0.035^{* * *} \\
(3.00)\end{array}$ & $\begin{array}{c}0.036^{* * *} \\
(3.37)\end{array}$ & $\begin{array}{c}0.035^{* * *} \\
(3.17)\end{array}$ & $\begin{array}{c}0.034^{* * *} \\
(3.14)\end{array}$ & $\begin{array}{c}0.034^{* * *} \\
(3.14)\end{array}$ & $\begin{array}{c}0.035^{* * *} \\
(3.16)\end{array}$ \\
\hline Observations & 55,596 & 55,596 & 55,596 & 55,596 & 55,596 & 55,596 \\
\hline Country & 79 & 79 & 79 & 79 & 79 & 79 \\
\hline Country dummies & yes & yes & yes & yes & yes & yes \\
\hline Sector-year dummies & yes & yes & yes & yes & yes & yes \\
\hline Firm and country-level controls & yes & yes & yes & yes & yes & yes \\
\hline
\end{tabular}

Robust standard errors clustered at the country level. $t$-Student in parenthesis. ${ }^{* * *} \mathrm{p}<0.01,{ }^{* *} \mathrm{p}<0.05,{ }^{*} \mathrm{p}<0.1$.

\section{Conclusion}

In this article, we examine whether financial deepening contributes to the growth of the private sector in developing and emerging countries. More specifically, we investigate how the more or less even distribution of credit across firms in a sector affects firm performance, as well as the role played by the banking market structure. We find that financial inclusion has a positive impact on the growth of firms and that bank competition (lower bank concentration) magnifies this effect. The positive interaction between financial inclusion and bank competition suggests they may be complementary.

We also find that bank concentration may favor firm performance in developing and emerging countries. This result is in line with a slew of recent literature which underlines how suboptimal business environments and cream-skimming strategies by entering banks may undermine the expected benefits of bank competition. We also find that such effects are gradually eliminated by economic development and financial inclusion. 
We test the robustness of these results by using alternative definitions of financial inclusion and bank competition. We also test our model on sub-samples of countries from different continents and by restricting analysis to the manufacturing sector. We not only find similar results as in the baseline estimate, but also infer that financial inclusion is particularly important in the less developed countries, where financial inclusions is lower, bank concentration higher and the relative gains of financial inclusion and financial reform more significant.

Finally, we use the firm and country-level heterogeneity in the data to refine our analysis of the effect of financial inclusion and bank concentration on firm performance. While financial inclusion is found to benefit firms of all sizes, irrespective of whether they export or not, we find that foreign firms benefit most from financial inclusion and bank concentration and that state-owned firms benefit most from bank concentration. This may reflect privileged access to credit that these types of firms may enjoy in some developing and emerging countries.

These conclusions suggest that insufficient financial inclusion represents one channel which, along with weak governance, institutions, and large information asymmetries, reduces the expected benefits from the development of banking systems in developing countries. A narrow client base and credit portfolios highly concentrated on government debt and a minority of large, often international, private firms seem to largely dampen the benefits of financial development, notably in the poorest countries. These results suggest that the expected benefits of financial deepening and competition for firm performance can only be seen when the bank client base and bank credit portfolios become more inclusive.

Financial development policy should therefore include specific plans to enhance financial inclusion, alongside financial market development and credit growth. Such strategic plans involve reducing information asymmetries, which may induce credit rationing from credit institutions, increasing consumer protection, and improving the business climate of the banking sector. If overdraft facilities remain the cornerstone of access to credit in these countries, diversifying credit access towards long-term credit is also paramount.

Further research is clearly needed to bring light to the impact of financial inclusion on economic performance in developing and emerging countries. Beyond firm growth, the relationship between financial inclusion and productivity and export performance might be of interest, as well as studies focusing on price effects, credit rationing and the business environment of the banking sector to explain and reduce financial exclusion. We believe that focusing further on variables that measure the quality of financial development, such as financial inclusion and the modalities of bank competition, brings an exciting new dimension to the analysis of financial development, especially in developing and emerging countries where the size alone of the 
financial sector may not be the most significant variable of interest or policy focus. 


\section{References}

Abdmoulah, Walid and Riadh Ben Jelili. 2013. "Access to Finance Thresholds and the Finance-Growth Nexus." Economic Papers: A journal of Applied Economics and Policy 32 (4):522-534.

Arcand, Jean Louis, Enrico Berkes, and Ugo Panizza. 2015. "Too much finance?" Journal of Economic Growth 20 (2):105-148.

Beck, Thorsten, Berrak Büyükkarabacak, Felix K Rioja, Neven T Valev et al. 2012. "Who gets the credit? And does it matter? Household vs. firm lending across countries." The BE Journal of Macroeconomics $12(1): 1-46$.

Beck, Thorsten, Olivier De Jonghe, and Glenn Schepens. 2013. "Bank competition and stability: crosscountry heterogeneity." Journal of Financial Intermediation 22 (2):218-244.

Beck, Thorsten, Asli Demirguc-Kunt, and Vojislav Maksimovic. 2005. "Financial and Legal Constraints to Growth: Does Firm Size Matter?" Journal of Finance 60 (1):137-177.

Claessens, Stijn and Neeltje Horen. 2014. "Foreign banks: Trends and impact." Journal of Money, Credit and Banking 46 (s1):295-326.

De la Torre, Augusto, María Soledad Martínez Pería, and Sergio L Schmukler. 2010. "Bank involvement with SMEs: Beyond relationship lending." Journal of Banking E Finance 34 (9):2280-2293.

Deidda, Luca and Bassam Fattouh. 2002. "Non-linearity between finance and growth." Economics Letters $74(3): 339-345$.

Deidda, Luca G. 2006. "Interaction between economic and financial development." Journal of Monetary Economics 53 (2):233-248.

Demetriades, Panicos and Siong Hook Law. 2006. "Finance, institutions and economic development." International Journal of Finance 83 Economics 11 (3):245-260.

Demirguc-Kunt, Asli, Luc Laeven, and Ross Levine. 2004. "Regulations, market structure, institutions, and the cost of financial intermediation." Journal of Money, Credit and Banking 36 (3):593-622.

Demirguc-Kunt, Asli, Ross Levine, and Hong-Ghi Min. 1998. "Opening to Foreign Banks: Issues of Stability, Efficiency, and Growth." In The Implications of Globalization of World Financial Markets, edited by ed. Seongtae Lee. Seoul, Korea: The Bank of Korea, 1-46. 
Detragiache, Enrica, Thierry Tressel, and Poonam Gupta. 2008. "Foreign banks in poor countries: theory and evidence." The Journal of Finance 63 (5):2123-2160.

Easterly, William, Roumeen Islam, and Joseph E Stiglitz. 2001. "Shaken and stirred: explaining growth volatility." In Annual World Bank Conference on Development Economics, vol. 191. 211.

GPFI. 2013. "The 20 basic set of financial inclusion indicators." Global Partnership for Financial Inclusion April.

GPFI, Global Partnership for financial inclusion. 2011. SME Finance Policy Guide. IFC, Washington, DC.

Guérineau, Samuel and Luc Jacolin. 2014. "L’inclusion financiére en Afrique sub-saharienne: Faits stylisés et déterminants." Revue d'économie financiére 116 (4):57-80.

Harrison, Ann E, Justin Yifu Lin, and Lixin Colin Xu. 2014. "Explaining Africa's (dis)advantage." World Development 63:59-77.

Harrison, Ann E and Margaret S McMillan. 2003. "Does direct foreign investment affect domestic credit constraints?" Journal of International Economics 61 (1):73-100.

Henderson, Daniel J, Chris Papageorgiou, and Christopher F Parmeter. 2013. "Who benefits from financial development? New methods, new evidence." European Economic Review 63:47-67.

Hermes, Niels and Robert Lensink. 2003. "Foreign direct investment, financial development and economic growth." The Journal of Development Studies 40 (1):142-163.

Kaufmann, Daniel, Aart Kraay, and Massimo Mastruzzi. 2011. "The worldwide governance indicators: methodology and analytical issues." Hague Journal on the Rule of Law 3 (2):220-246.

Loayza, Norman V and Romain Ranciere. 2006. "Financial development, financial fragility, and growth." Journal of Money, Credit and Banking :1051-1076.

Méon, Pierre-Guillaume and Laurent Weill. 2010. "Does financial intermediation matter for macroeconomic performance?" Economic Modelling 27 (1):296-303.

Moulton, Brent R. 1990. "An Illustration of a Pitfall in Estimating the Effects of Aggregate Variables on Micro Units." The Review of Economics and Statistics 72 (2):pp. 334-338.

Northcott, Carol Ann. 2004. "Competition in Banking: A Review of the Literature." In Staff Working Papers. Published by the Bank of Canada. 
Philippon, Thomas and Ariell Reshef. 2013. "An international look at the growth of modern finance." The Journal of Economic Perspectives :73-96.

Rajan, Raghuram G. and Luigi Zingales. 1998. "Financial Dependence and Growth." American Economic Review :559-586.

Rajan, Raghuram G and Luigi Zingales. 2003. "The great reversals: the politics of financial development in the twentieth century." Journal of Financial Economics 69 (1):5-50.

Rioja, Felix and Neven Valev. 2004. "Does one size fit all?: a reexamination of the finance and growth relationship." Journal of Development Economics 74 (2):429-447.

Rousseau, Peter L and Paul Wachtel. 2002. "Inflation thresholds and the finance-growth nexus." Journal of International Money and Finance 21 (6):777-793. 


\section{Appendix A}

Table A.1: List of countries, survey years, and number of observations.

\begin{tabular}{|c|c|c|c|c|c|c|c|c|c|c|}
\hline Country & 2006 & 2007 & 2008 & 2009 & 2010 & 2011 & 2012 & 2013 & 2014 & Total \\
\hline Albania & 0 & 121 & 0 & 0 & 0 & 0 & 0 & 137 & 0 & 258 \\
\hline Antigua and Barbuda & 0 & 0 & 0 & 0 & 119 & 0 & 0 & 0 & 0 & 119 \\
\hline Argentina* & 757 & 0 & 0 & 0 & 818 & 0 & 0 & 0 & 0 & 1,575 \\
\hline Armenia & 0 & 0 & 0 & 192 & 0 & 0 & 0 & 205 & 0 & 397 \\
\hline Azerbaijan & 0 & 0 & 0 & 316 & 0 & 0 & 0 & 142 & 0 & 458 \\
\hline Bangladesh* & 0 & 0 & 0 & 0 & 0 & 0 & 0 & 1,306 & 0 & 1,306 \\
\hline Belarus & 0 & 0 & 174 & 0 & 0 & 0 & 0 & 209 & 0 & 383 \\
\hline Belize & 0 & 0 & 0 & 0 & 144 & 0 & 0 & 0 & 0 & 144 \\
\hline Benin & 0 & 0 & 0 & 95 & 0 & 0 & 0 & 0 & 0 & 95 \\
\hline Bolivia* & 392 & 0 & 0 & 0 & 140 & 0 & 0 & 0 & 0 & 532 \\
\hline Bosnia & 0 & 0 & 0 & 237 & 0 & 0 & 0 & 280 & 0 & 517 \\
\hline Botswana* & 252 & 0 & 0 & 0 & 191 & 0 & 0 & 0 & 0 & 443 \\
\hline Brazil* & 0 & 0 & 0 & 988 & 0 & 0 & 0 & 0 & 0 & 988 \\
\hline Burkina Faso* & 0 & 0 & 0 & 304 & 0 & 0 & 0 & 0 & 0 & 304 \\
\hline Cameroon* & 0 & 0 & 0 & 314 & 0 & 0 & 0 & 0 & 0 & 314 \\
\hline Cape Verde* & 0 & 0 & 0 & 77 & 0 & 0 & 0 & 0 & 0 & 77 \\
\hline Chile* & 737 & 0 & 0 & 0 & 855 & 0 & 0 & 0 & 0 & 1,592 \\
\hline China & 0 & 0 & 0 & 0 & 0 & 0 & 2,441 & 0 & 0 & 2,441 \\
\hline Colombia* & 790 & 0 & 0 & 0 & 824 & 0 & 0 & 0 & 0 & 1,614 \\
\hline Costa Rica & 0 & 0 & 0 & 0 & 326 & 0 & 0 & 0 & 0 & 326 \\
\hline Djibouti & 0 & 0 & 0 & 0 & 0 & 0 & 0 & 63 & 0 & 63 \\
\hline Dominican Republic & 0 & 0 & 0 & 0 & 275 & 0 & 0 & 0 & 0 & 275 \\
\hline Ecuador* & 441 & 0 & 0 & 0 & 296 & 0 & 0 & 0 & 0 & 737 \\
\hline Egypt & 0 & 0 & 0 & 0 & 0 & 0 & 0 & 1,948 & 0 & 1,948 \\
\hline El Salvador* & 521 & 0 & 0 & 0 & 262 & 0 & 0 & 0 & 0 & 783 \\
\hline Ethiopia & 0 & 0 & 0 & 0 & 0 & 328 & 0 & 0 & 0 & 328 \\
\hline Gabon & 0 & 0 & 0 & 83 & 0 & 0 & 0 & 0 & 0 & 83 \\
\hline Gambia & 120 & 0 & 0 & 0 & 0 & 0 & 0 & 0 & 0 & 120 \\
\hline Georgia & 0 & 0 & 211 & 0 & 0 & 0 & 0 & 193 & 0 & 404 \\
\hline Ghana & 0 & 436 & 0 & 0 & 0 & 0 & 0 & 459 & 0 & 895 \\
\hline Guatemala* & 439 & 0 & 0 & 0 & 373 & 0 & 0 & 0 & 0 & 812 \\
\hline Guyana & 0 & 0 & 0 & 0 & 121 & 0 & 0 & 0 & 0 & 121 \\
\hline Honduras* & 348 & 0 & 0 & 0 & 215 & 0 & 0 & 0 & 0 & 563 \\
\hline India & 0 & 0 & 0 & 0 & 0 & 0 & 0 & 0 & 8,168 & 8,168 \\
\hline Indonesia & 0 & 0 & 0 & 1,089 & 0 & 0 & 0 & 0 & 0 & 1,089 \\
\hline Jordan & 0 & 0 & 0 & 0 & 0 & 0 & 0 & 429 & 0 & 429 \\
\hline Kazakhstan & 0 & 0 & 0 & 350 & 0 & 0 & 0 & 281 & 0 & 631 \\
\hline Kenya & 0 & 578 & 0 & 0 & 0 & 0 & 0 & 591 & 0 & 1,169 \\
\hline Kyrgyzstan & 0 & 0 & 0 & 162 & 0 & 0 & 0 & 0 & 0 & 162 \\
\hline Laos & 0 & 0 & 0 & 346 & 0 & 0 & 177 & 0 & 0 & 523 \\
\hline Lebanon & 0 & 0 & 0 & 0 & 0 & 0 & 0 & 381 & 0 & 381 \\
\hline Lesotho & 0 & 0 & 0 & 112 & 0 & 0 & 0 & 0 & 0 & 112 \\
\hline
\end{tabular}

Countries with a star are those for which we can include a firm fixed-effect. 
Table A.1: continued.

\begin{tabular}{|c|c|c|c|c|c|c|c|c|c|c|}
\hline Country & 2006 & 2007 & 2008 & 2009 & 2010 & 2011 & 2012 & 2013 & 2014 & Total \\
\hline Macedonia, & 0 & 0 & 0 & 258 & 0 & 0 & 0 & 327 & 0 & 585 \\
\hline Madagascar & 0 & 0 & 0 & 288 & 0 & 0 & 0 & 280 & 0 & 568 \\
\hline Malawi* & 0 & 0 & 0 & 104 & 0 & 0 & 0 & 0 & 293 & 397 \\
\hline Mali & 0 & 423 & 0 & 0 & 80 & 0 & 0 & 0 & 0 & 503 \\
\hline Mauritius & 0 & 0 & 0 & 295 & 0 & 0 & 0 & 0 & 0 & 295 \\
\hline Mexico* & 1,097 & 0 & 0 & 0 & 1,22 & 0 & 0 & 0 & 0 & 2,317 \\
\hline Moldova & 0 & 0 & 0 & 328 & 0 & 0 & 0 & 265 & 0 & 593 \\
\hline Mongolia & 0 & 0 & 0 & 350 & 0 & 0 & 0 & 274 & 0 & 624 \\
\hline Montenegro & 0 & 0 & 0 & 67 & 0 & 0 & 0 & 96 & 0 & 163 \\
\hline Morocco & 0 & 0 & 0 & 0 & 0 & 0 & 0 & 322 & 0 & 322 \\
\hline Mozambique & 0 & 431 & 0 & 0 & 0 & 0 & 0 & 0 & 0 & 431 \\
\hline Namibia & 236 & 0 & 0 & 0 & 0 & 0 & 0 & 0 & 144 & 380 \\
\hline Nicaragua* & 390 & 0 & 0 & 0 & 248 & 0 & 0 & 0 & 0 & 638 \\
\hline Niger* & 0 & 0 & 0 & 97 & 0 & 0 & 0 & 0 & 0 & 97 \\
\hline Pakistan* & 0 & 736 & 0 & 0 & 0 & 0 & 0 & 505 & 0 & 1,241 \\
\hline Panama* & 333 & 0 & 0 & 0 & 129 & 0 & 0 & 0 & 0 & 462 \\
\hline Paraguay* & 334 & 0 & 0 & 0 & 257 & 0 & 0 & 0 & 0 & 591 \\
\hline Peru* & 545 & 0 & 0 & 0 & 815 & 0 & 0 & 0 & 0 & 1,36 \\
\hline Philippines & 0 & 0 & 0 & 910 & 0 & 0 & 0 & 0 & 0 & 910 \\
\hline Rwanda & 157 & 0 & 0 & 0 & 0 & 0 & 0 & 0 & 0 & 157 \\
\hline Samoa & 0 & 0 & 0 & 66 & 0 & 0 & 0 & 0 & 0 & 66 \\
\hline Senegal* & 0 & 411 & 0 & 0 & 0 & 0 & 0 & 0 & 343 & 754 \\
\hline Serbia & 0 & 0 & 0 & 314 & 0 & 0 & 0 & 283 & 0 & 597 \\
\hline South Africa & 0 & 812 & 0 & 0 & 0 & 0 & 0 & 0 & 0 & 812 \\
\hline St. Lucia & 0 & 0 & 0 & 0 & 130 & 0 & 0 & 0 & 0 & 130 \\
\hline Suriname & 0 & 0 & 0 & 0 & 152 & 0 & 0 & 0 & 0 & 152 \\
\hline Swaziland & 206 & 0 & 0 & 0 & 0 & 0 & 0 & 0 & 0 & 206 \\
\hline Tajikistan & 0 & 0 & 218 & 0 & 0 & 0 & 0 & 170 & 0 & 388 \\
\hline Tanzania & 367 & 0 & 0 & 0 & 0 & 0 & 0 & 344 & 0 & 711 \\
\hline Togo & 0 & 0 & 0 & 89 & 0 & 0 & 0 & 0 & 0 & 89 \\
\hline Tunisia & 0 & 0 & 0 & 0 & 0 & 0 & 0 & 557 & 0 & 557 \\
\hline Turkey & 0 & 0 & 594 & 0 & 0 & 0 & 0 & 658 & 0 & 1,252 \\
\hline Uganda & 516 & 0 & 0 & 0 & 0 & 0 & 0 & 355 & 0 & 871 \\
\hline Uruguay* & 376 & 0 & 0 & 0 & 397 & 0 & 0 & 0 & 0 & 773 \\
\hline Venezuela* & 0 & 0 & 0 & 0 & 135 & 0 & 0 & 0 & 0 & 135 \\
\hline Vietnam & 0 & 0 & 0 & 858 & 0 & 0 & 0 & 0 & 0 & 858 \\
\hline Zambia & 0 & 406 & 0 & 0 & 0 & 0 & 0 & 526 & 0 & 932 \\
\hline Total & 9,354 & 4,354 & 1,197 & 8,689 & 8,522 & 328 & 2,618 & 11,586 & 8,948 & 55,596 \\
\hline
\end{tabular}

Countries with a star are those for which we can include a firm fixed-effect. 
Table A.2: List of sectors

\begin{tabular}{lrr}
\hline Sector & Frequency & Percent \\
\cline { 1 - 2 } Food & 6,568 & 11.81 \\
Tobacco & 154 & 0.28 \\
Textile & 3,093 & 5.56 \\
Garments & 3,858 & 6.94 \\
Leather & 789 & 1.42 \\
Wood & 970 & 1.74 \\
Paper & 561 & 1.01 \\
Publishing & 1,136 & 2.04 \\
Chemicals and refined petroleum & 3,369 & 6.06 \\
Rubber and plastics & 2,187 & 3.93 \\
Metallic and non-metallic mineral products & 3,568 & 6.42 \\
Fabricated metal products & 2,885 & 5.19 \\
Machinery and equipment & 1,892 & 3.40 \\
Electronics & 1,403 & 2.52 \\
Motor vehicles & 987 & 1.78 \\
Furniture & 1,702 & 3.06 \\
Other manufacturing & 1,037 & 1.87 \\
Retail trade & 2,496 & 4.49 \\
Wholesale trade & 5,521 & 9.93 \\
IT & 820 & 1.47 \\
Transport and construction & 6,013 & 10.82 \\
Hotel & 2,132 & 3.83 \\
Other services & 2,455 & 4.42 \\
\hline Total & 55,596 & 100.00 \\
\hline
\end{tabular}




\title{
Documents de Travail
}

600. M. Mogliani and T. Ferrière, "Rationality of announcements, business cycle asymmetry, and predictability of revisions. The case of French GDP” September 2016

601. R. S.J. Koijen; F. Koulischer; B. Nguyen and M. Yogo, "Quantitative Easing in the Euro Area: The Dynamics of Risk Exposures and the Impact on Asset Prices" September 2016

602. O. de Bandt and M. Chahad, “A DGSE Model to Assess the Post-Crisis Regulation of Universal Banks” September 2016

603. C. Malgouyres, "The Impact of Chinese Import Competition on the Local Structure of Employment and Wages: Evidence from France" September 2016

604. G. Cette, J. Lopez and J. Mairesse, "Labour market regulations and capital labour substitution” October 2016

605. C. Hémet and C. Malgouyres, "Diversity and Employment Prospects: Neighbors Matter!” October 2016

606. M. Ben Salem and B. Castelletti-Font, "Which combination of fiscal and external imbalances to determine the longrun dynamics of sovereign bond yields?" November 2016

607. M. Joëts, V. Mignon and T. Razafindrabe, "Does the volatility of commodity prices reflect macroeconomic uncertainty?" November 2016

608. M. Bussière, G. Gaulier and W. Steingress, "Global Trade Flows: Revisiting the Exchange Rate Elasticities" November 2016

609. V.Coudert and J. Idier, “An Early Warning System for Macro-prudential Policy in France” November 2016

610. S. Guilloux-Nefussi, “Globalization, Market Structure and Inflation Dynamics” December 2016

611. S.Fries, J-S. Mésonnier, S. Mouabbi, and J-P. Renne, "National natural rates of interest and the single monetary policy in the Euro Area" December 2016

612. J. Blaum, C. Lelarge and M. Peters, “The Gains from Input Trade with Heterogeneous Importers” December 2016

613. A. Penalver, “Optimal Monitoring of Long-Term Loan Contracts” December 2016

614. M. Isoré and U. Szczerbowicz, "Disaster Risk and Preference Shifts in a New Keynesian Model” December 2016

615. L. Chauvet and L. Jacolin, "Financial Inclusion, Bank Concentration and Firm Performance” December 2016

Pour accéder à la liste complète des Documents de Travail publiés par la Banque de France veuillez consulter le site : www.banque-france.fr

For a complete list of Working Papers published by the Banque de France, please visit the website: www.banque-france.fr

Pour tous commentaires ou demandes sur les Documents de Travail, contacter la bibliothèque de la Direction Générale des Études et des Relations Internationales à l'adresse suivante :

For any comment or enquiries on the Working Papers, contact the library of the Directorate General Economics and International Relations at the following address :

\author{
BANQUE DE FRANCE \\ 49- 1404 Labolog \\ 75049 Paris Cedex 01 \\ tél : 0033 (0)14297 7724 ou 0142926340 ou 4890 ou 6981 \\ email : 1404-ut@banque-france.fr
}

